Hal 29-35

\title{
PENERAPAN KOMPRES HANGAT DALAM MENURUNKAN HIPERTERMIA PADA ANAK YANG MENGALAMI KEJANG DEMAM SEDERHANA \\ Nova Ari Pangesti ${ }^{1}$, Bayu Seto Rindi Atmojo ${ }^{2}$ Kiki A $^{3}$ \\ Akademi Keperawatan Pemkab Purworejo \\ Purworejo, (0275) 3140576 \\ E-mail : nopheexcellent@gmail.com
}

\begin{abstract}
ABSTRAK
Latar Belakang : Kejang demam merupakan bangkitan kejang yang terjadi akibat kenaikkan suhu mencapai $38^{\circ} \mathrm{C}$, karena proses ekstrakranium, biasanya terjadi pada usia dibawah 5 tahun. Kejang demam sederhana merupakan kejang bersifat umum berlangsung beberapa detik dan kurang dari 15 menit. Tujuan: untuk menganalisa suhu partisipan yang mengalami hipertermi dengan diberikan kompres hangat di RSUD Dr. Tjitrowardojo Purworejo. Metode: Penelitian menggunakan metode deskriptif dalam bentuk studi kasus. Subjek dalam penelitian ini 2 orang pasien anak dan keluarganya yang mengalami kejang demam sederhana. Hasil: setelah dilakukan pemberian kompres hangat pada partisipan 1 dan partisipan 2 selama 3 hari menunjukkan bahwa suhu partisipan 1 menurun dari $38.5^{\circ} \mathrm{C}$ menjadi dari $36.3^{\circ} \mathrm{C}$ dan partisipan 2 juga menurun dari $38.2^{\circ} \mathrm{C}$ menjadi $37.0^{\circ} \mathrm{C}$. Kesimpulan: Pemberian kompres hangat merupakan tindakan yang efektif untuk menurunkan suhu pada partisipan yang mengalami hipertermi.
\end{abstract}

Kata kunci : Kejang Demam, Hipertermi, Kompres Hangat

\begin{abstract}
Background: Febrile seizures are seizures that occur due to temperature increases reaching $38^{\circ} \mathrm{C}$, because the extracranium process, usually occurs at the age of under 5 years. Simple febrile seizures are generic seizures lasting several seconds and less than 15 minutes. Objective: to analyze the temperature of participants who have hyperthermia by giving a warm compress at RSUD Dr. Tjitrowardojo Purworejo. Methods: The study used a descriptive method in the form of case studies. The subjects in this study were 2 pediatric patients and their families who experienced simple febrile seizures. Results: after giving warm compresses to participant 1 and participant 2 for 3 days showed that the temperature of participant 1 decreased from $38.5^{\circ} \mathrm{C}$ to $36.3^{\circ} \mathrm{C}$ and participant 2 also decreased from $38.2^{\circ} \mathrm{C}$ to $37.0^{\circ} \mathrm{C}$. Conclusion: Giving warm compresses is an effective action to reduce temperature in participants who experience hyperthermia.
\end{abstract}

Keywords : Febrile Convulsion, Hyperthermia, Warm Compress 


\section{Latar Belakang}

Masa anak merupakan masa pertumbuhan dan masa perkembangan yang dimulai dari bayi (0-1 tahun), usia bermain/oddler (1-1,5 tahun), dan pra-sekolah (2.5-5 tahun). Dalam proses pertumbuhan dan perkembangan anak biasanya rentang sakit (Aziz, 2005). Para ahli menggolongkan usia balita pada usia pra-sekolah 3 - 4 tahun sebagai tahapan perkembangan anak yang cukup rentan terhadap berbagai serangan penyakit dan penyakit yang sering dijumpai adalah penyakit infeksi (Wong, 2009).

World Health Organization (WHO) menyatakan bahwa hasil studi yang dilakukan pada 400 anak usia 1 bulan - 13 tahun dengan riwayat kejang, paling banyak anak menderita kejang demam 77\%. Di Indonesia dilaporkan pada tahun 2012 - 2013 angka kejadian kejang demam 3-4\% dari anak yang berusia 6 bulan 5 tahun (Wibisono,2015).

Di RSUD Dr. Tjitrowardojo dilaporkan angka kejadian kejang demam pada usia $1-5$ tahun di tahun 2016-2017 dari 162 menjadi 172. Kejang demam sangat dipengaruhi oleh faktor usia, hampir tidak pernah ditemukan sebelum usia 6 bulan dan setelah 6 tahun (Hull, 2008).

Kejang demam merupakan bangkitan kejang yang terjadi pada kenaikan suhu $38^{\circ} \mathrm{C}$, yang disebabkan oleh suatu proses ekstrakranium, biasanya terjadi pada usia 3 bulan - 5 tahun (Sujono \& Suharsono, 2010).

Kejang demam merupakan kelainan neurologist yang paling sering dijumpai pada anak, terutama pada anak umur 6 bulan sampai 4 tahun. Hampir 3\% dari anak yang berumur dibawah 5 tahun pernah menderita kejang demam (Ngastiyah, 2014). Kejang demam dibagi menjadi dua yaitu kejang demam sederhana dan kejang demam kompleks.

Menurut Riyadi, (2013) kondisi yang menyebabkan kejang demam antara lain : infeksi yang mengenai jaringan ektrakranial seperti tonsilitis, ototis media akut, bronkitis. Adapun menurut IDAI, (2013) penyebab terjadinya kejang demam, antara lain: obatobatan, ketidakseimbangan kimiawi seperti hiperkalemia, hipoglikemia dan asidosis, demam, patologis otak, eklampsia (ibu yang mengalami hipertensi prenatal, toksimea gravidarum). Sejalan menurut Airlangga Universty Press (AUP), (2015) dimana kejang demam (febris convulsion/stuip/step) yaitu kejang yang timbul pada waktu demam yang tidak disebabkan oleh proses di dalam kepala (otak: seperti meningitis atau radang selaput otak, ensifilitis atau radang otak) tetapi diluar kepala misalnya karena ada nya infeksi di saluran pernapasan, telinga atau infeksi di saluran pencernaan. Biasanya dialami anak usia 6 bulan sampai 5 tahun.

Kejang demam dibagi menjadi dua yaitu kejang demam sederhana dan kejang demam kompleks. Anak-anak yang mengalami kejang demam sederhana tidak memiliki peningkatan resiko kematian. Pada kejang demam kompleks yang terjadi sebelum usia 1 tahun, atau dipicu oleh kenaikan suhu $<39^{\circ} \mathrm{C}$ dikaitkan dengan angka kematian 2 kali lipat selama 2 tahun pertama setelah terjadinya kejang (Wulandari \& Erawati, 2016).

Okti S, dkk (2008) menyatakan bahwa pada keadaan demam kenaikan suhu $1{ }^{\circ} \mathrm{C}$ akan 
mengakibatkan kenaikan metabolisme basal 10- $15 \%$ dan kebutuhan oksigen meningkat 20\%. Kenaikan suhu tubuh tertentu dapat mempengaruhi keseimbangan dari membrane sel neuron dan dalam waktu yang singkat terjadi difusi dari ion kalium dan natrium dari membrane tadi, akibat lepasnya muatan listrik. Lepasnya muatan listrik ini demikan besar sehingga dapat meluas keseluruh sel maupun membrane sel tetangganya dengan bantuan neurotransmitter dan terjadilah kejang.

Pada anak yang panas perawat sering melakukan kegiatan untuk penurunan panas tersebut salah satunya dengan kompres (Sri P, dkk, 2008). Sri dan Winarsih (2008) yang melaporkan penelitian Swardana, dkk (1998) menyatakan bahwa menggunakan air dapat memelihara suhu tubuh sesuai dengan fluktuasi suhu tubuh pasien. Kompres hangat dapat menurunkan suhu tubuh melalui proses evaporasi. Hasil penelitiaannya Swardana, dkk (1998) yang berjudul pengaruh kompres hangat terhadap perubahan suhu tubuh menunjukkan adanya perbedaan efektifitas kompres dingin dan kompres hangat dalam menurunkan suhu tubuh.

Kompres hangat telah diketahui mempunyai manfaat yang baik dalam menurunkan suhu tubuh anak yang mengalami panas tinggi di rumah sakit karena menderita berbagai penyakit infeksi. Sri dan Winarsih (2008) yang melaporkan penelitian tahun (2002) oleh Tri Redjeki menyatakan bahwa kompres hangat lebih banyak menurunkan suhu tubuh dibandingkan dengan kompres air dingin, karena akan terjadi vasokontriksi pembuluh darah, pasien menjadi menggigil.
Dengan kompres hangat menyebabkan suhu tubuh diluaran akan terjadi hangat sehingga tubuh akan menginterpretasikan bahwa suhu diluaran cukup panas, akhirnya tubuh akan menurunkan kontrol pengatur suhu di otak supaya tidak meningkatkan suhu pengatur tubuh, dengan suhu diluaran hangat akan membuat pembuluh darah tepi dikulit melebar dan mengalami vasodilatasi sehingga pori pori kulit akan membuka dan mempermudah pengeluaran panas. Sehingga akan terjadi perubahan suhu tubuh.

Berdasarkan paparan di atas, penulis tertarik membahas mengenai penerapan kompres hangat dalam menurunkan hipertermia pada anak yang mengalami kejang demam sederhana .

\section{Metode}

Desain penelitian ini adalah deskriptif, dalam bentuk studi kasus yang mengeksplor penerapan kompres hangat dalam menurunkan hipertermia pada anak yang mengalami kejang demam sederhana. Subyek dala penelitian ini adalah dua orang klien 2 orang pasien anak dan keluarganya yang mengalami kejang demam sederhana.

Pelaksanaan pengumpulan data dilakukan di Ruang Tulip bangsal anak RSUD Dr. Tjitrowardojo Purworejo pada An. A yang pada tanggal 28 Januari 2019 - 30 Januari 2019, dan partisipan 2 yaitu An. H yang dilakukan tanggal 31 Januari 2019 - 02 Februari 2019

Pengumpulan data tentang penerapan kompres hangat dalam menurunkan hipertermia pada anak yang mengalami kejang demam sederhana, yaitu: 
1. Observasi

Dalam penelitian ini, penulis mengobservasi atau melihat keadaan umum partisipan dengan pemeriksaan fisik (dengan pendekatan IPPA : inspeksi, palpasi, perkusi, dan auskultasi).

2. Pengukuran

Dalam penelitian ini, penulis mengukur menggunakan alat ukur pemeriksaan, seperti melakukan pengukuran TTV khususnya suhu tubuh.

3. Wawancara

Dalam penelitian ini wawancara yang dilakukan dengan menggunakan wawancara. Wawancara jenis ini merupakan kombinasi dari wawancara tidak terpimpin dan wawancara terpimpin.

4. Dokumentasi

Dokumentasi yang dilakukan oleh penulisyaitu pendokumentasi hasil pengkajian, analisa data, diagnosa keperawatan, rencana keperawatan, tindakan keperawatan, dan evaluasi dari tindakan.

Instrumen pengumpulan data yang meliputi:

1. Memberikan kompres hangat dengan menggunakan SOP Rumah Sakit.

2. Thermometer aksila

Uji keabsahan data dimaksudkan untuk menguji kualitas data atau informasi yang diperoleh dalam penelitian sehingga menghasilkan data dengan validitas tinggi. Triangulasi dalam penelitian ini menggunakan triangulasi observasi, yaitu hasil pengukuran post test dan triangulasi waktu, yaitu dilakukan dengan mengukur suhu tubuh setelah diberikan kompres hangat.

\section{Hasil}

An. A berusia 1 tahun 6 bulan mengalami kejang demam pertama kali dan partisipan An. H berusia 2 tahun mengalami kejang demam pertama kali. An. A dan An. $\mathrm{H}$ berjenis kelamin laki - laki dan diagnosa saat dirawat adalah kejang demam sederhana.

Dari hasil partisipan I menunjukkan bahwa keluhan utama pada An. A yaitu ibu An. A mengatakan anak mengalami demam dan kejang ( \pm 10 menit), sedangkan hasil dari partisipan II pada An. H ibu An. H mengatakan anaknya demam, muntah \pm 5 kali dan anak mengalami kejang ( \pm 3 menit).

Dari hasil pemeriksaan kedua pertisipan ibu partisipan mengatakan An. A dan An. H sebelum mengalami kejang partisipan didahului mengalami peningkatan suhu tubuh dengan suhu tubuh An. A $\left(38.5^{\circ} \mathrm{C}\right)$ dan An. H $\left(38.2^{\circ} \mathrm{C}\right)$.

Implementasi yang di Memberikan kompres hangat : partisipan 1: Dilakukan tindakan kompres hangat saat suhu tubuh masih tinggi dan pemberian antipiretik, partisipan 2 : Tidak dilakukan tindakan kompres hangat, hanya diberikan obat antipiretik. Jadi, terdapat perbedaan penurunan suhu pada partisipan 1 dan partisipan 2. Pada partisipan 1 yang diberi tindakan kompres hangat dan pemberian antipiretik selama 3 hari didapatkan hasil suhu tubuh partisipan 1 turun $\pm 1.9^{\circ} \mathrm{C}$, sedangkan pada partisipan 2 yang hanya diberi obat antipiretik selama 3 hari didapatkan hasil suhu tubuh partisipan 2 turun $\pm 1.5^{\circ} \mathrm{C}$. 
Evaluasi dari hasil perbandingan implementasi antara partisipan I (An. A) yang dilakukan kompres hangat dengan partisipan II (An. H) yang tidak dilakukan kompres hangat adalah bahwa suhu tubuh cepat turun jika dilakukan pemberian kompres hangat ditambah dengan obat antipiretik daripada tidak diberikan kompres hangat. Didapatkan hasil pada An.A suhu tubuh awal $38.2^{\circ} \mathrm{C}$ setelah dilakukan kompres hangat ditambah dengan obat antipiretik selama tiga hari menjadi $36.3^{\circ} \mathrm{C}$, telah terjadi penurunan $\pm 1.9^{\circ} \mathrm{C}$. sedangkan pada An. $\mathrm{H}$ yang tidak dilakukan kompres hangat tetapi hanya dengan obat antipiretik suhu awal $38.5^{\circ} \mathrm{C}$ selama tiga hari menjadi $37.0^{\circ} \mathrm{C}$, telah terjadi penurunan $\pm 1.5^{\circ} \mathrm{C}$.

\section{Pembahasan}

1. Gambaran suhu tubuh sebelum diberikan terapi kompres hangat

Pada Tn S sebelum dilakukan tindakan keperawatan skala nyeri yang dirasakan yaitu 4. Sedangkan pada Tn W skala nyeri awal yang terasa skala 3 .

Kejang demam adalah serangan kejang yang terjadi karena kenaikan suhu tubuh yaitu di atas $38^{\circ} \mathrm{C}$ yang sering dijumpai pada usia anak dibawah lima tahun (Subiyanto, 2010).

Menurut Analisa peneliti masalah hipertermi yang muncul pada An. H karena anak sudah terjadi infeksi didalam tubuhnya hal ini didukung juga dari pemeriksaan laboratorium yang terjadi peningkatan leukosit (18.2) batas normal $(6.0$ - 17.5). Kejang demam, terjadi pada hari pertama demam, serangan pertama jarang sekali terjadi pada usia $<6$ bulan atau > 3 tahun. Gejala: anak tidak sadar, kejang tampak sebagai gerakan-gerakan seluruh tangan dan kaki yang terjadi dalam waktu sangat singkat

Demam atau panas pada anak itu umumnya justru dibutuhkan sebagai salah satu bentuk perlawanan tubuh terhadap infeksi. Tetapi apakah ada sisi negatifnya. Kerugian yang bisa terjadi akibat demam antara lain gangguan tumbuh kembang, sulit konsentrasi, hambatan dalam aktivitas sehari-sehari seperti sekolah, bermain, dll. Selain itu kejang demam dapat menyebabkan kerusakan pada otak dan menimbulkan epilepsi. Menurut Taslim, (2013) kejang demam yang di perkirakan setiap tahun nya terjadi pada anak sebagian besar mengalami komplikasi epilepsi. Di indonesia sendiri komplikasi yang terjadi karena kejadian kejang demam berupa kejang berulang, epilepsi, dan hemiparese.

Saat anak terjadi kejang demam tidak ditangani dengan baik oleh orang tua, maka resiko terjadi kejang demam berulang sangat besar. Oleh karena itu orang tua perlu diberikan pemahaman tentang tatalaksana penanganan demam seperti kompres hangat.

2. Gambaran Intensitas nyeri setelah dierikan relaksasi nafas dalam

Didapatkan hasil pada An.A suhu tubuh awal $38.2^{\circ} \mathrm{C}$ setelah dilakukan kompres hangat ditambah dengan obat antipiretik selama tiga hari menjadi $36.3^{\circ} \mathrm{C}$, telah terjadi penurunan $\pm 1.9^{\circ} \mathrm{C}$. sedangkan pada An. H suhu awal $38.5^{\circ} \mathrm{C}$ selama tiga hari menjadi $37.0^{\circ} \mathrm{C}$, telah 
terjadi penurunan $\pm 1.5^{\circ} \mathrm{C}$. Kompres hangat diberikan dengan waktu 30 menit dengan suhu air hangat $\pm 34{ }^{\circ} \mathrm{C}-37^{\circ} \mathrm{C}$. Kompres hangat diberikan 2 jam sebelum pemberian terapi obat parasetamol.

Kompres hangat tindakan melapisi permukaan kulit dengan handuk yang telah dibasahi air hangat dengan temperatur 30oC-35oC (Maling, 2012). Kompres yang benar yaitu menggunakan air hangat karena jika menggunakan air hangat maka akan terjadi pelebaran pembuluh darah yang akan menyebabkan lancarnya pembuluh darah dan cepatnya pengeluran kringat sehingga suhu tubuh cepat turun.

Menurut Purwanti, (2008) cit Mohamad, (2011) tindakan memberikan kompres hangat pada pasien bertujuan menurunkan suhu tubuh melalui proses evaporasi, yaitu hilangnya panas dengan proses keluarnya keringat di bagian kulit tersebut menguap. Tindakan kompres hangat dilakukan pada leher, kedua axila, kedua selangkangan, dan kedua lipatan lutut bagian dalam, dimana area tersebut terdapat pembuluh darah yang besar sehingga akan cepat dalam memberikan atau menghantarkan sinyal ke hipotalamus untuk meningkatkan penguapan dan menurunkan suhu tubuh.

Hal ini menyatakan bahwa keefektifan kompres hangat untuk mengatasi demam dikemukakan oleh Fatmawati Mohamad (2012) dalam jurnal penelitiannya yang berjudul Efektifitas
Kompres Air Hangat Terhadap Penurunan Suhu Tubuh Anak Demam, mengemukakan bahwa tindakan alternatif yang paling efektif untuk mengatasi hipertermi adalah dengan cara mengompres air hangat. Disamping itu sesuai dengan penelitiannya Sri Purwanti (2008) yang menyatakan pengaruh kompres hangat terhadap perubahan suhu tubuh pada pasien anak dengan hipertermi.

Sejalan dengan penelitian terdapat rerata suhu tubuh pasien sebelum dilakukan tindakan kompres hangat sebesar $38,9^{\circ} \mathrm{C}$, dan setelah mendapat perlakuan kompres hangat selama 10 menit menjadi berubah sebesar $37,9^{\circ} \mathrm{C}$ sehingga membuktikan ada pengaruh kompres hangat terhadap perubahan suhu tubuh dengan nilai $\mathrm{P}=0,001$.

\section{Kesimpulan}

Berdasarkan penjelasan di atas, dapat disimpulkan bahwa pemberian kompres hangat merupakan tindakan yang efektif untuk menurunkan suhu pada partisipan yang mengalami hipertermi.

\section{Ucapan Terima Kasih}

Dalam hal ini penulis mengucapkan terima kasih kepada Direktur Akper Pemkab Purworejo dan Ketua Lembaga Penelitian dan Pengabdian Masyarakat yang telah memberikan dukungan moril maupun materiil dalam penyelesaian publikasi ini. 


\section{Daftar Pustaka}

Brunner \& Suddarth. 2013. Keperawatan Medikal-Bedah. Jakarta : EGC

Aminatul Fatayati \& Umu Hani Edi Nawangsih, 2010. Pengaruh Pemberian Kompres Hangat Terhadap Penurunan Suhu Badan Pada Balita.

Attila Dewanti, dkk, 2012. Kejang Demam Dan Faktor Yang Mempengaruhi Rekurensi. Sari Pediatri, Vol. 14, No. 1.

Carison, dkk, 2018. Tatalaksana Terkini Demam Pada Anak. Jurnal Kedokteran Meditek Vol. 24, No. 67, Juli - Sept 2018.

Fadil \& Akmal Hasan, 2018. Pengaruh Kompres Hangat Terhadap Perubahan Suhu Tubuh Pada Pasien Febris. Jurnal Ilmiah Kesehatan Pencerah ISSN 2089-9394, Vol. 1. No. 2.

Fuadi, dkk, 2010. Faktor Resiko Bangkitan Kejang Demam Pada Anak. Sari Pediatri, Vol. 12, No. 3. Fatmawati Mohamad, 2012. Efektifitas Kompres Hangat Dalam Menurunkan Demam. Jurnal Health and Sport ejournal.ung.ac.id

Hidayat, A. Aziz Alimul. 2005. Pengantar Ilmu keperawatan Anak, Edisi 1. Salemba Medika : Jakarta.

IDAI. (2013). Kejang Demam Anak, (Online). Http:www.idai.or.id/main.php.pdf> (diakses pada tanggal 29 Juni 2018).

Inke Nadia Diniyanti Lubis \& Chairuddin Panusunan Lubis. Penanganan Demam Pada Anak. Sari Pediatri, Vol. 12, No. 6.

Jenyfer P. Kakalang, dkk, 2016. Profil Kejang Demam. Jurnal e-Clinic (eCI), Vol. 4, No. 2, Juli - Desember 2016.

Melda Deliana, 2002. Tata Laksana Kejang Demam Pada Anak. Sari Pediatri, Vol.4, No. 2, September 2002 : 59 62.
Ngastiyah, 2014. Perawatan Anak Sakit / Ngastiyah; editor, Setiawan - Jakarta : EGC.

Okti Sri Purwanti \& Arina Maliya, 2008. Kegawatdaruratan Kejang Demam Pada Anak. Journal Berita Ilmu Keperawatan, Vol. 1, No. 2.

Reva Indriyani, 2017. Asuhan Keperawatan Pada Anak yang Mengalami Kejang Demam Dengan Hipertermia.

Riyadi \& Ratnaningsih. (2013). Tumbang cara praktis untuk memantau pertumbuhan dan perkembangan anak. Yogyakarta : Pustaka Pelajar.

Sri Hartini \& Putri Pandu Pertiwi, 2015. Efektifitas Kompres Air Hangat Terhadap Penurunan Suhu Tubuh Anak Demam Usia 1-3 Tahun Di SMC RS Telogorejo Semarang. Karya Ilmiah - ejournal.stikestelogorejo.ac.id

Sri Purwanti \& Winarsih Nur Ambarwati, 2008. Pengaruh Kompres Hangat Terhadap Perubahan Suhu Tubuh Pada Pasien Anak Hipertermia. Jurnal Berita Ilmu Keperawatan ISSN 19792697, Vol. 1. No. 2.

Subiyanto (2010). Asuhan Keperawatan Anak Dengan Kejang Demam (http://teguhsubianto.blogspot.com, diakses 29 Maret 2020) 